\title{
SAFETY ASSESSMENT AND THE EFFECT OF SQUALENE ISOLATED FROM Schizochytrium mangrovei PQ6 ON SERUM HDL - CHOLESTEROL LEVELS IN ANIMAL MODELS
}

\author{
Nguyen Cam Ha ${ }^{1,2}$, Hoang Thi Minh Hien ${ }^{1}$, Nguyen Hoang Ngan ${ }^{3}$, Dang Diem Hong, ${ }^{1,2,4, *}$ \\ ${ }^{1}$ Institute of Biotechnology, VAST, Vietnam \\ ${ }^{2}$ Graduate University of Science and Technology, VAST, Vietnam \\ ${ }^{3}$ Vietnam Military Medical University, Ha Noi, Vietnam \\ ${ }^{4}$ Thuyloi University, Ha Noi, Vietnam
}

Received 22 February 2019, accepted 22 Apirl 2019

\begin{abstract}
In this paper, the acute and subchronic toxicity and the effect of squalene isolated from heterotrophic marine microalga Schizochytrium mangrovei PQ6 on the serum levels of HDL-C were investigated using animal models. The results of acute toxicity study showed that by oral administration of the squalene on albino mice at the highest dose of $58.25 \mathrm{~g} / \mathrm{kg}$ of whole body of mice/day, the $\mathrm{LD}_{50}$ was not determined. Squalene at doses of $400 \mathrm{mg} / \mathrm{kg} / \mathrm{day}$ and $1,200 \mathrm{mg} / \mathrm{kg} / \mathrm{day}$ for 60 consecutive days have allowed the normal behavior, body weight, hematological and biochemical parameters, liver and kidney functions, morphology of liver, kidney and spleen, total plasma cholesterol content, however, HDL-C level was higher in squalene treated mices compared to control group $(p<0.05$ ). In addition, at doses of 600 and 1,200 mg/kg/day for 60 continuous days, squalene treated mice showed the increase in HDL-C level and HDL-C/total cholesterol ratio and the decrease in the contents of LDL-C and VLDL-C without affecting the body and liver weights and levels of total cholesterol and triglyceride.
\end{abstract}

Keyworlds: Schizochytrium mangrovei PQ6, acute toxicity, high density lipoprotein (HDL)cholesterol, squalene, subchronic toxicity.

Citation: Nguyen Cam Ha, Hoang Thi Minh Hien, Nguyen Hoang Ngan, Dang Diem Hong, 2019. Safety assessment and the effect of squalene isolated from Schizochytrium mangrovei PQ6 on serum HDL - cholesterol levels in animal models. Tap chi Sinh hoc, 41(2): 39-48. https://doi.org/10.15625/0866-7160/v41n2.13629.

*Corresponding author email: ddhong60vn@yahoo.com,ddhong@ibt.ac.vn

(C2019 Vietnam Academy of Science and Technology (VAST) 


\title{
ĐÁNH GIÁ MỨC ĐỘ AN TOÀN VÀ TÁC DƯNG CỦA SQUALENE TÁCH CHIÊT TỪ Schizochytrium mangrovei PQ6 ĐẾN SỰ TĂNG CHOLESTEROL CỦA LIPOPROTEIN TỶ TRỌNG CAO (HDL-C) Ở ĐộNG VẬT THỰC NGHIỆM
}

\author{
Nguyễn Cẩm Hà ${ }^{1,2}$, Hoàng Thị Minh Hiền ${ }^{1}$, Nguyễn Hoàng Ngân ${ }^{3}$, Đặng Diễm Hồng ${ }^{1,2,4, *}$ \\ ${ }^{1}$ Viện Công nghệ sinh học, Viện Hàn lâm Khoa học và Công nghệ Việt Nam, Việt Nam \\ ${ }^{2}$ Học viện Khoa học và Công nghệ, Viện Hàn lâm Khoa học và Công nghệ Việt Nam, Việt Nam \\ ${ }^{3}$ Học Viện Quân y, Hà Nội, Việt Nam \\ ${ }^{4}$ Đại học Thủy Lợi, Hà Nội, Việt Nam
}

Ngày nhận bài 22-2-2019, ngày chấp nhận 22-4-2019

\section{TÓM TÁT}

Trong nghiên cứu này, độc tính cấp, bán trường diễn và tác dụng tăng hàm lượng HDL-C của squalene được tách chiết từ Schizochytrium mangrovei PQ6 đã được thử nghiệm trên mô hình động vật. Kết quả chưa tìm thấy $\mathrm{LD}_{50}$ của squalene theo đường uống trên chuột nhắt trắng với mức liều cao nhất có thể cho uống trong một lần tương đương $58,25 \mathrm{~g} / \mathrm{kg}$ thể trọng. Đồng thời, squalene với liều $400 \mathrm{mg} / \mathrm{kg} / \mathrm{ngày}$ và $1.200 \mathrm{mg} / \mathrm{kg} / \mathrm{ngày} \mathrm{không} \mathrm{gây} \mathrm{ảnh} \mathrm{hưởng} \mathrm{đến} \mathrm{hoạt} \mathrm{động,}$ thể trọng, chức năng tạo máu, chức năng gan, chức năng thận cũng như mô bệnh học gan, thận trong suốt quá trình uống liên tục 60 ngày; ngoại trừ, hàm lượng HDL-C ở các lô dùng squalene tăng hơn so với đối chứng $(p<0,05)$. Bên cạnh đó, kết quả nghiên cứu tác dụng dược lý của squalene trên chuột nhắt trắng với liều uống 600 và $1.200 \mathrm{mg} / \mathrm{kg} / \mathrm{ngày} \mathrm{liên} \mathrm{tục} \mathrm{trong} 60$ ngày cho thấy, squalene đã có tác dụng tăng HDL-C và tỷ lệ HDL-C/cholesterol toàn phần trong máu, làm giảm cholesterol gắn với lipoprotein tỷ trọng thấp (LDL-C) và lipoprotein tỷ trọng rất thấp (VLDL-C) trong máu nhưng không gây ảnh hưởng đến sự phát triển cân nặng cơ thể và gan, cholesterol toàn phần và triglycerit (TG) máu.

Từ khóa: Schizochytrium mangrovei PQ6, bán trường diễn, độc tính cấp, HDL-cholesterol, squalene.

*Địa chỉ liên hệ email: ddhong60vn@yahoo.com, ddhong@ibt.ac.vn

\section{MỞ ĐẦU}

Squalene là tiền chất steroit của động thực vật và là chất chống oxi hóa (Kohno et al., 1995). Gần đây, squalene được sử dụng như là chất có tác dụng chữa bệnh, giảm nguy cơ ung thư ruột, phổi, da... do các tác nhân hoá học, làm tăng đáng kể chức năng miễn dịch của tế bào và miễn dịch không đặc hiệu phụ thuộc vào liều lượng (Smith, 2000). Ngoài ra, squalene còn có tác dụng làm giảm hàm lượng cholesterol tổng số, cholesterol gắn với lipoprotein tỷ trọng thấp (LDL-C) (Chan et al., 1996). Việc hấp thụ lượng squalene > $500 \mathrm{mg} /$ người có tác dụng giúp giảm đáng kể các bệnh về tim mạch và ung thư. Vì vậy, chúng cũng được sử dụng phổ biến trong dược phẩm.

Ở Việt Nam, squalene đã được tách chiết và làm sạch thành công ở Schizochytrium mangrovei PQ6 (Nguyen et al., 2016); đã nghiên cứu được tác dụng và cơ chế tác dụng giảm lipit của squalene là kích hoạt thụ thể PPAR $\alpha$ (Peroxisome proliferator-activated receptor $\alpha$ ), thụ thể gan LXRs (Liver $\mathrm{X}$ receptor), các gen tham gia vào quá trình vận chuyển ngược và thoái hóa cholesterol (Hoang et al., 2016; Hoang et al., 2017). Tuy nhiên, các nghiên cứu về độc tính cấp và bán trường diễn cũng như tác dụng tăng HDL-C của squalene ở mô hình động vật vẫn chưa được nghiên cứu. 


\section{VÂT LIỆU VÀ PHƯƠNG PHÁP NGHIÊN} CƯU

Chuột thí nghiệm do Ban động vật thí nghiệm, Học viện Quân y cung cấp, được nuôi trong phòng nuôi động vật thí nghiệm một tuần trước khi nghiên cứu bằng thức ăn chuẩn dành cho động vật nghiên cứu và uống tự do nước sạch.

Thức ăn cho chuột thí nghiệm được phòng nghiên cứu Dược lý, Học viện Quân y sản xuất và lượng thức ăn (gram) được cung cấp theo công thức sau: Bột mỳ- 200, bột ngô250, Bột sữa- 100, bột đỗ tương- 200, bột cá$200, \mathrm{CaCl} 2-5, \mathrm{NaCl}-5$, dầu đậu nành- 40 và 2 viên vitamin tổng hợp. Các nguyên liệu khô được trộn đều, làm thành bánh, sấy khô đến khối lượng không đổi, bảo quản trong thùng chứa chuyên dụng.

Máy xét nghiệm sinh hoá Biochemical Systems International Srl, Italia, model 3000 Evolution, hóa chất của hãng; Máy phân tích huyết học Humancout 30TS, hãng Human, Đức; Sử dụng phần mềm phân tích huyết học dành cho chuột thí nghiệm; hóa chất của các hãng; Cân phân tích $10^{-4}$, model CP224S (Sartorius, Đức);

Squalene được tách chiết từ sinh khối khô loài Schizochytrium mangrovei $\mathrm{PQ6}$ theo nhu mô tả của Nguyen et al. (2016). Cấu trúc của squalene sau đó được phân tích phổ cộng hưởng từ hạt nhân (NMR) và đối chiếu với tài liệu tham khảo (Pouchert \& Behnke, 1993).

Nghiên cứu độc tính cấp và xác định $\mathrm{LD}_{50}$ bằng đường uống theo phương pháp của Litchfield - Wincoxon (Đỗ Trung Đàm, 2014). Trong đó, chuột nhắt trắng chủng Swiss gồm 40 con (18-22 g) được chia ngẫu nhiên thành 5 lô, mỗi lô 08 con. Cho chuột uống squalene không pha loãng với các mức liều tăng dần. Qua đó, xác định liều cao nhất không gây chết chuột, liều thấp nhất gây chết $100 \%$ số chuột và các liều trung gian.

Độc tính bán trường diễn được đánh giá theo qui định của Bộ Y tế Việt Nam (2018). Trong đó, chuột cống trắng dòng Wistar gồm 24 con (160-180 g), được chia ngẫu nhiên thành 3 lô, mỗi lô 08 con. Công thức thí nghiệm gồm: Lô chứng: uống dầu oliver liều
$1,00 \mathrm{~mL} / \mathrm{kg} / 24$ giờ; Lô trị 1: uống squalene (pha trong dầu oliver), liều $400 \mathrm{mg} / \mathrm{kg} / \mathrm{ngày}$; Lô trị 2: uống squalene (pha trong dầu oliver) liều $1.200 \mathrm{mg} / \mathrm{kg} /$ ngày. Các thông số như chức năng máu, gan, thận và lách được theo dõi và kiểm tra vào trước lúc uống squalene $\left(\mathrm{D}_{0}\right)$, ngày thứ $30\left(\mathrm{D}_{30}\right)$ và ngày thứ $60\left(\mathrm{D}_{60}\right)$ của nghiên cứu.

Mô bệnh học: Sau 60 ngày uống squalene, chuột được mổ để quan sát đại thể toàn bộ các cơ quan. Kiểm tra ngẫu nhiền cấu trúc vi thể gan, lách, thận của ít nhất $30 \%$ số chuột ở mỗi lô. Các xét nghiệm vi thể được thực hiện tại Bộ môn khoa Giải phẫu bệnh - Pháp y, Bệnh viện Quân y 103.

Tác dụng làm tăng HDL-C của squalene: được tiến hành đánh giá trên chuột nhắt trắng theo phương pháp được mô tả bởi Clara Gaba's-Rivera và cộng sự (Đỗ Trung Đàm, 2006). Chuột nhắt trắng chủng Swiss gồm 24 con (18-22 g), chia ngẫu nhiên thành 3 lô, mỗi lô 8 con bao gồm: Lô 1 (chứng): uống dầu oliver; Lô 2 (trị 1): uống squalene (pha trong dầu oliver) liều $600 \mathrm{mg} / \mathrm{kg} / \mathrm{ngày}$; Lô 3 (trị 2): uống squalene (pha trong dầu oliver) liều $1.200 \mathrm{mg} / \mathrm{kg} /$ ngày. Cuối thí nghiệm giết chuột, đánh giá các chỉ tiêu: Cân nặng cơ thể (thể trọng), cân nặng gan; Cholesterol toàn phần, HDL-C, LDL-C, VLDL-C, tỷ lệ HDL$\mathrm{C} /$ cholesterol toàn phần; TG máu.

Các số liệu được xử lý theo các phương pháp thống kề y sinh học, so sánh bằng anova test sử dụng phần mềm SPSS 16.0. Số liệu được biểu diễn dưới dạng $\bar{X} \pm S D$. Sự khác biệt có ý nghĩa thống kê khi $p<0,05$.

\section{KẾT QUẢ VÀ THẢO LUẬN}

Kết quả nghiên cứu cho thấy, không có chuột nào bị chết sau khi uống squalene một lần duy nhất với các liều khác nhau từ thấp nhất là $10 \mathrm{ml} / \mathrm{kg}$ thể trọng đến cao nhất là $50 \mathrm{ml} / \mathrm{kg}$ thể trọng (tương đương với 11,65 và $58,25 \mathrm{~g} / \mathrm{kg}$ thể trọng). Sau 72 đến 168 giờ, chuột hoạt động bình thường (ăn uống, bài tiết, lông mượt, mắt trong (bảng 1)).

Kết quả thu được của chúng tôi hoàn toàn phù hợp với công bố của CTFA (1971) với liều uống cao nhất $50 \mathrm{ml} / \mathrm{kg}$ khối lượng cơ thể 
chuột trong vòng 7 ngày, squalene đã không gây độc và gây chết ở chuột được cho uống.
Do đó, chúng tôi kết luận rằng squalene tách chiết từ $S$. mangrovei $\mathrm{PQ6}$ không độc.

Bảng 1 . Độc tính cấp theo đường uống của squalene trên chuột nhắt trắng

\begin{tabular}{|c|c|c|c|c|c|}
\hline $\begin{array}{c}\text { Lô } \\
\text { chuột }\end{array}$ & $\begin{array}{c}\text { Số chuột thí } \\
\text { nghiệm }\end{array}$ & $\begin{array}{c}\text { Liều dùng } \\
\text { (ml/kg thể } \\
\text { trọng) }\end{array}$ & $\begin{array}{c}\text { Liều dùng } \\
\text { (g/kg thề } \\
\text { trọng) }\end{array}$ & $\begin{array}{c}\text { Số chuột } \\
\text { sông/chêt sau } \\
72 \text { giờ }\end{array}$ & $\begin{array}{c}\text { Số chuột } \\
\text { sông/chêt sau } \\
168 \text { giờ }\end{array}$ \\
\hline Lô 1 & 08 & 10 & 11,65 & $08 / 0$ & $08 / 0$ \\
\hline Lô 2 & 08 & 20 & 23,30 & $08 / 0$ & $08 / 0$ \\
\hline Lô 3 & 08 & 30 & 34,95 & $08 / 0$ & $08 / 0$ \\
\hline Lô 4 & 08 & 40 & 46,60 & $08 / 0$ & $08 / 0$ \\
\hline Lô 5 & 08 & 50 & 58,25 & $08 / 0$ & $08 / 0$ \\
\hline
\end{tabular}

Ảnh hưởng của squalene lên tình trạng chung và sự thay đổi thể trọng của chuột cống trắng khi dùng dài ngày

Tình trạng chung: Chuột cống trắng ở cả lô chứng và lô dùng squalene đều hoạt động bình thường, có lông mượt, da niêm mạc và ăn uống bình thường, phân thành khuôn.

Sự thay đổi thể trọng: Kết quả cho thấy, khối lượng chuột trong các lô chứng và thí nghiệm đều tăng có ý nghĩa thống kê sau 30 và 60 ngày so với trước thí nghiệm $(p<0,05)$. Không có sự sai khác về thể trọng của chuột ở hai lô uống squalene so với lô chứng tại tất cả các thời điểm đo $(p>0,05)$ (bảng 2$)$. Như vậy, với các mức liều và thời gian sử dụng squalene chưa thấy gây ra các thay đổi về phát triển thể trọng của chuột.

Bảng 2. Ảnh hưởng của squalene lên thể trọng chuột cống trắng

\begin{tabular}{|c|c|c|c|c|c|}
\hline \multirow{2}{*}{$\begin{array}{l}\text { Thời điểm } \\
\text { xét nghiệm }\end{array}$} & \multirow{2}{*}{ Thể trọng $(\mathrm{g})$} & \multicolumn{3}{|c|}{ Lô nghiên cứu } & \multirow{2}{*}{$p$} \\
\hline & & Lô chứng (1) & Lô trị 1 (2) & Lô trị 2 (3) & \\
\hline \multirow{3}{*}{$\begin{array}{l}\text { Trước thí } \\
\text { nghiệm (a) }\end{array}$} & $\mathrm{n}$ & 8 & 8 & 8 & \multirow{3}{*}{$\begin{array}{l}p_{2-1}>0,05 \\
p_{3-2}>0,05 \\
p_{3-1}>0,05\end{array}$} \\
\hline & $\bar{X}$ & 169,75 & 167,75 & 168,63 & \\
\hline & SD & 5,06 & 4,37 & 4,00 & \\
\hline \multirow{3}{*}{$\begin{array}{l}\text { Sau } 30 \text { ngày } \\
\text { (b) }\end{array}$} & $\mathrm{n}$ & 8 & 8 & 8 & \multirow{3}{*}{$\begin{array}{l}p_{2-1}>0,05 \\
p_{3-2}>0,05 \\
p_{3-1}>0,05\end{array}$} \\
\hline & $\overline{\bar{X}}$ & 196,00 & 195,13 & 195,88 & \\
\hline & SD & 9,17 & 9,98 & 8,97 & \\
\hline \multirow{3}{*}{$\begin{array}{l}\text { Sau } 60 \text { ngày } \\
\text { (c) }\end{array}$} & $\mathrm{n}$ & 8 & 8 & 8 & \multirow{3}{*}{$\begin{array}{l}p_{2-1}>0,05 \\
p_{3-2}>0,05 \\
p_{3-1}>0,05\end{array}$} \\
\hline & $\bar{X}$ & 209,50 & 207,25 & 208,50 & \\
\hline & SD & 7,07 & 8,36 & 6,61 & \\
\hline & \multicolumn{3}{|c|}{$p_{b-a}<0,05 ; p_{c-b}<0,05 ; p_{c-a}<0,05$} & - \\
\hline
\end{tabular}

Ghi chú: n: Số chuột trong lô; Lô chứng: uống dầu oliver liều $1,00 \mathrm{~mL} / \mathrm{kg} / \mathrm{ngày;} \mathrm{Lô} \mathrm{trị} \mathrm{1:} \mathrm{uống}$ squalene (pha trong dầu oliver), liều $400 \mathrm{mg} / \mathrm{kg} / \mathrm{ngày}$; Lô trị 2: uống squalene (pha trong dầu oliver) liều $1.200 \mathrm{mg} / \mathrm{kg} / \mathrm{ngày}$.

Ảnh hưởng của squalene đối với một số chỉ tiêu huyết học và sinh hóa của chuột

Kết quả trong bảng 3 cho thấy, không có sự khác biệt về các chỉ tiêu huyết học và sinh hóa trong máu chuột giữa nhóm chứng và 2 nhóm trị trước và sau 30, 60 ngày thí nghiệm. Như vậy, squalene với các mức liều và thời gian khác nhau trong nghiên cứu đã không làm thay đổi các chỉ tiêu chức năng tạo máu của chuột. 
Bảng 3. Ảnh hưởng của squalene lên một số chỉ tiêu huyết học trong máu chuột ( $\mathrm{n}=8, \bar{X} \pm \mathrm{SD}$ )

\begin{tabular}{|c|c|c|c|c|}
\hline Thời điểm xét nghiệm & Lô chứng (1) & Lô trị $1(2)$ & Lô trị 2(3) & $p$ \\
\hline \multicolumn{4}{|l|}{ Chỉ tiêu huyết học } & \\
\hline \multicolumn{5}{|c|}{ Số lượng hồng cầu chuột $\left(\times 10^{12} \mathrm{~g} / \mathrm{L}\right)$} \\
\hline Trước thí nghiệm (a) & $8,13 \pm 0,67$ & $8,11 \pm 0,75$ & $8,20 \pm 1,16$ & \multirow{3}{*}{$\begin{array}{l}p_{2-1}>0,05 \\
p_{3-2}>0,05 \\
p_{3-1}>0,05\end{array}$} \\
\hline Sau 30 ngày (b) & $8,18 \pm 0,44$ & $8,20 \pm 0,80$ & $8,12 \pm 0,55$ & \\
\hline Sau 60 ngày (c) & $8,15 \pm 1,12$ & $8,09 \pm 0,61$ & $8,23 \pm 0,99$ & \\
\hline $\mathrm{p}$ & \multicolumn{3}{|c|}{$p_{b-a}>0,05 ; p_{c-b}>0,05 ; p_{c-a}>0,05$} & - \\
\hline \multicolumn{5}{|c|}{ Hàm lượng huyết sắc tố trong máu chuột (g/L) } \\
\hline Trước thí nghiệm (a) & $130,50 \pm 7,69$ & $132,13 \pm 14,93$ & $130,75 \pm 13,80$ & \multirow{3}{*}{$\begin{array}{l}p_{2-1}>0,05 \\
p_{3-2}>0,05 \\
p_{3-1}>0,05\end{array}$} \\
\hline Sau 30 ngày (b) & $129,63 \pm 11,50$ & $131,13 \pm 6,24$ & $129,88 \pm 9,40$ & \\
\hline Sau 60 ngày (c) & $129,38 \pm 6,35$ & $130,75 \pm 6,96$ & $131,63 \pm 8,23$ & \\
\hline $\mathrm{p}$ & \multicolumn{3}{|c|}{$p_{b-a}>0,05 ; p_{c-b}>0,05 ; p_{c-a}>0,05$} & - \\
\hline \multicolumn{5}{|l|}{ Hematocrit (\%) } \\
\hline Trước thí nghiệm (a) & $41,10 \pm 2,33$ & $40,16 \pm 4,45$ & $40,22 \pm 3,09$ & \multirow{3}{*}{$\begin{array}{l}p_{2-1}>0,05 \\
p_{3-2}>0,05 \\
p_{3-1}>0,05\end{array}$} \\
\hline Sau 30 ngày (b) & $40,79 \pm 2,76$ & $40,12 \pm 2,36$ & $40,83 \pm 2,53$ & \\
\hline Sau 60 ngày (c) & $40,44 \pm 4,55$ & $40,90 \pm 3,50$ & $40,60 \pm 3,70$ & \\
\hline $\mathrm{p}$ & \multicolumn{3}{|c|}{$p_{b-a}>0,05 ; p_{c-b}>0,05 ; p_{c-a}>0,05$} & - \\
\hline \multicolumn{5}{|c|}{ Thể tích trung bình hồng cầu (fL) } \\
\hline Trước thí nghiệm (a) & $48,25 \pm 4,86$ & $48,63 \pm 3,42$ & $49,00 \pm 3,02$ & \multirow{3}{*}{$\begin{array}{l}p_{2-1}>0,05 \\
p_{3-2}>0,05 \\
p_{3-1}>0,05\end{array}$} \\
\hline Sau 30 ngày (b) & $47,75 \pm 3,01$ & $48,13 \pm 4,52$ & $48,50 \pm 4,11$ & \\
\hline Sau 60 ngày (c) & $48,38 \pm 4,27$ & $48,88 \pm 3,98$ & $49,25 \pm 4,33$ & \\
\hline $\mathrm{p}$ & \multicolumn{3}{|c|}{$p_{b-a}>0,05 ; p_{c-b}>0,05 ; p_{c-a}>0,05$} & - \\
\hline \multicolumn{5}{|l|}{ Số lượng bạch cầu $(\mathrm{g} / \mathrm{L})$} \\
\hline Trước thí nghiệm (a) & $8,85 \pm 1,37$ & $8,89 \pm 1,20$ & $9,04 \pm 1,73$ & \multirow{3}{*}{$\begin{array}{l}p_{2-1}>0,05 \\
p_{3-2}>0,05 \\
p_{3-1}>0,05\end{array}$} \\
\hline Sau 30 ngày (b) & $8,75 \pm 1,97$ & $9,06 \pm 1,31$ & $9,01 \pm 1,48$ & \\
\hline Sau 60 ngày (c) & $8,92 \pm 1,73$ & $8,99 \pm 0,70$ & $9,13 \pm 1,56$ & \\
\hline $\mathrm{p}$ & \multicolumn{3}{|c|}{$p_{b-a}>0,05 ; p_{c-b}>0,05 ; p_{c-a}>0,05$} & - \\
\hline \multicolumn{5}{|l|}{ Số lượng tiểu cầu $(\mathrm{g} / \mathrm{L})$} \\
\hline Trước thí nghiệm (a) & $683,38 \pm 110,27$ & $731,88 \pm 197,83$ & $673,00 \pm 71,75$ & \multirow{3}{*}{$\begin{array}{l}p_{2-1}>0,05 \\
p_{3-2}>0,05 \\
p_{3-1}>0,05\end{array}$} \\
\hline Sau 30 ngày (b) & $654,88 \pm 119,94$ & $633,13 \pm 127,28$ & $677,25 \pm 105,23$ & \\
\hline Sau 60 ngày (c) & $686,63 \pm 134,80$ & $682,00 \pm 139,98$ & $691,63 \pm 82,75$ & \\
\hline $\mathrm{p}$ & \multicolumn{3}{|c|}{$p_{b-a}>0,05 ; p_{c-b}>0,05 ; p_{c-a}>0,05$} & - \\
\hline \multicolumn{5}{|l|}{ Chỉ số sinh hóa } \\
\hline \multicolumn{5}{|l|}{ Hoạt độ AST (UI/L) } \\
\hline Trước thí nghiệm (a) & $77,50 \pm 11,76$ & $80,88 \pm 12,29$ & $75,63 \pm 15,70$ & \multirow{3}{*}{$\begin{array}{l}p_{2-1}>0,05 \\
p_{3-2}>0,05 \\
p_{3-1}>0,05\end{array}$} \\
\hline Sau 30 ngày (b) & $79,13 \pm 12,39$ & $75,50 \pm 18,21$ & $74,75 \pm 16,39$ & \\
\hline Sau 60 ngày (c) & $76,88 \pm 9,46$ & $74,13 \pm 16,38$ & $73,63 \pm 15,13$ & \\
\hline $\mathrm{p}$ & \multicolumn{3}{|c|}{$p_{b-a}>0,05 ; p_{c-b}>0,05 ; p_{c-a}>0,05$} & \\
\hline \multicolumn{5}{|l|}{ Hoạt độ ALT (UI/L) } \\
\hline Trước thí nghiệm (a) & $72,88 \pm 19,29$ & $70,63 \pm 12,57$ & $72,50 \pm 17,53$ & \multirow{2}{*}{$\begin{array}{l}p_{2-1}>0,05 \\
p_{3-2}>0,05\end{array}$} \\
\hline Sau 30 ngày (b) & $73,75 \pm 20,97$ & $68,38 \pm 19,91$ & $70,13 \pm 18,21$ & \\
\hline
\end{tabular}


Nguyen Cam Ha etl al.

\begin{tabular}{|c|c|c|c|c|}
\hline Sau 60 ngày (c) & $70,75 \pm 17,10$ & $71,25 \pm 13,05$ & $69,75 \pm 20,15$ & $p_{3-1}>0,05$ \\
\hline $\mathrm{p}$ & \multicolumn{3}{|c|}{$p_{b-a}>0,05 ; p_{c-b}>0,05 ; p_{c-a}>0,05$} & \\
\hline \multicolumn{5}{|c|}{ Bilirubin toàn phần $(\mathrm{g} / \mathrm{L})$} \\
\hline Trước thí nghiệm (a) & $75,75 \pm 29,68$ & $79,50 \pm 17,10$ & $75,38 \pm 18,33$ & \multirow{3}{*}{$\begin{array}{l}p_{2-1}>0,05 \\
p_{3-2}>0,05 \\
p_{3-1}>0,05\end{array}$} \\
\hline Sau 30 ngày (b) & $76,13 \pm 20,32$ & $74,25 \pm 19,36$ & $71,25 \pm 12,56$ & \\
\hline Sau 60 ngày (c) & $74,75 \pm 16,80$ & $71,75 \pm 13,58$ & $69,50 \pm 11,39$ & \\
\hline $\mathrm{p}$ & \multicolumn{3}{|c|}{$p_{b-a}>0,05 ; p_{c-b}>0,05 ; p_{c-a}>0,05$} & \\
\hline \multicolumn{5}{|c|}{ Albumin huyết tương $(\mathrm{g} / \mathrm{L})$} \\
\hline Trước thí nghiệm (a) & $31,50 \pm 3,74$ & $32,63 \pm 2,83$ & $31,75 \pm 3,20$ & \multirow{3}{*}{$\begin{array}{l}p_{2-1}>0,05 \\
p_{3-2}>0,05 \\
p_{3-1}>0,05\end{array}$} \\
\hline Sau 30 ngày (b) & $31,13 \pm 4,55$ & $32,25 \pm 3,99$ & $32,00 \pm 3,21$ & \\
\hline Sau 60 ngày (c) & $31,88 \pm 3,56$ & $32,13 \pm 3,64$ & $32,38 \pm 3,34$ & \\
\hline $\mathrm{p}$ & \multicolumn{3}{|c|}{$p_{b-a}>0,05 ; p_{c-b}>0,05 ; p_{c-a}>0,05$} & \\
\hline \multicolumn{5}{|c|}{ Cholesterol toàn phần (mmol/L) } \\
\hline Trước thí nghiệm (a) & $1,36 \pm 0,44$ & $1,35 \pm 0,36$ & $1,38 \pm 0,35$ & \multirow{3}{*}{$\begin{array}{l}p_{2-1}>0,05 \\
p_{3-2}>0,05 \\
p_{3-1}>0,05\end{array}$} \\
\hline Sau 30 ngày (b) & $1,46 \pm 0,42$ & $1,38 \pm 0,32$ & $1,41 \pm 0,29$ & \\
\hline Sau 60 ngày (c) & $1,49 \pm 0,29$ & $1,43 \pm 0,28$ & $1,45 \pm 0,26$ & \\
\hline $\mathrm{p}$ & \multicolumn{3}{|c|}{$p_{b-a}>0,05 ; p_{c-b}>0,05 ; p_{c-a}>0,05$} & \\
\hline \multicolumn{5}{|l|}{$\mathrm{HDL}-\mathrm{C}(\mathrm{mmol} / \mathrm{L})$} \\
\hline Trước thí nghiệm (a) & $0,73 \pm 0,16$ & $0,76 \pm 0,24$ & $0,77 \pm 0,22$ & $\begin{array}{l}p_{2-1}>0,05 \\
p_{3-1}>0,05 \\
p_{3-2}>0,05\end{array}$ \\
\hline Sau 30 ngày (b) & $0,75 \pm 0,18$ & $0,92 \pm 0,13$ & $0,93 \pm 0,20$ & $\begin{array}{c}0,05<p_{2-1}<0,1 \\
0,05<p_{3-1}<0,1 \\
p_{3-2}>0,05\end{array}$ \\
\hline Sau 60 ngày (c) & $0,79 \pm 0,15$ & $0,96 \pm 0,15$ & $0,98 \pm 0,12$ & $\begin{array}{l}p_{2-1}<0,05 \\
p_{3-1}<0,05 \\
p_{3-2}>0,05\end{array}$ \\
\hline $\mathrm{p}$ & $\begin{array}{l}p_{b-a}>0,05 \\
p_{c-a}>0,05 \\
p_{c-b}>0,05\end{array}$ & $\begin{array}{l}p_{b-a}<0,05 \\
p_{c-a}<0,05 \\
p_{c-b}>0,05\end{array}$ & $\begin{array}{l}p_{b-a}<0,05 \\
p_{c-a}<0,05 \\
p_{c-b}>0,05\end{array}$ & \\
\hline \multicolumn{5}{|l|}{ Creatinin $(\mu \mathrm{mol} / \mathrm{L})$} \\
\hline Trước thí nghiệm (a) & $71,13 \pm 19,95$ & $74,75 \pm 13,55$ & $77,25 \pm 8,45$ & \multirow{3}{*}{$\begin{array}{l}p_{2-1}>0,05 \\
p_{3-2}>0,05 \\
p_{3-1}>0,05\end{array}$} \\
\hline Sau 30 ngày (b) & $69,75 \pm 10,57$ & $70,25 \pm 17,99$ & $72,75 \pm 12,45$ & \\
\hline Sau 60 ngày $(\mathrm{c})$ & $72,00 \pm 16,22$ & $69,50 \pm 19,41$ & $71,25 \pm 19,37$ & \\
\hline $\mathrm{p}$ & \multicolumn{3}{|c|}{$p_{b-a}>0,05 ; p_{c-b}>0,05 ; p_{c-a}>0,05$} & \\
\hline
\end{tabular}

Ghi chú: Lô chứng: uống dầu oliver liều 1,00 mL/kg/ngày; Lô trị 1: uống squalene (pha trong dầu oliver), liều 400 mg/kg/ngày; Lô trị 2: uống squalene (pha trong dầu oliver) liều 1.200 mg/kg/ngày.

Ảnh hưởng của squalene sau 60 ngày dùng liên tục lên nồng độ HDL-C máu chuột ở các lô đối chứng và 2 lô trị được chỉ ra ở bảng 3 .

Trước khi thử nghiệm, không có sự khác biệt có ý nghĩa về chỉ số HDL-C giữa lô chứng và 2 lô trị, $(p>0,05)$. Sau 30 ngày và 60 ngày uống squalene, chỉ số HDL-C ở 2 lô trị đã tăng cao hơn khi so với cùng các lô đối chứng; tuy nhiên sự sai khác này chỉ có ý nghĩa thống kê sau 60 ngày chuột được cho uống squalene ( $p$ $<0,05$ ). Như vậy, squalene với các mức liều và thời gian sử dụng trong nghiên cứu đã thể hiện được tác dụng làm tăng chỉ số HDL-C trong máu chuột nghiên cứu. 
Đánh giá mức độ tổn thương tế bào gan và chức năng gan chuột khi dùng squalene dài ngày

Kết quả trong bảng 3 đã cho thấy sau 30 và 60 ngày uống squalene, hoạt độ của AST và $A L T$, bilirubin toàn phần, albumin huyết tương và cholesterol toàn phần đều không có sự khác biệt có ý nghĩa thống kê so với lô chứng và so sánh giữa các thời điểm trước và sau khi uống thuốc trị, $(p>0,05)$. Như vậy, squalene với các mức liều và thời gian sử dụng trong nghiên cứu không gây ảnh hưởng đến chức năng gan chuột trong nghiên cứu.

\section{Đánh giá ảnh hưởng lên chức năng thận của chuột khi dùng squalene dài ngày}

Sau 30 và 60 ngày uống squalene, chỉ số creatinin máu chuột ở cả 2 lô trị đều không có sự khác biệt có ý nghĩa thống kê so với lô đối chứng và so sánh giữa các thời điểm trước và sau khi thử nghiệm, $(p>0,05)$ (bảng 3). Như vậy, squalene với các mức liều và thời gian sử dụng trong nghiên cứu không ảnh hưởng lên chức năng thận của chuột nghiên cứu.

Giải phẫu mô bệnh học gan, thận, lách của chuột
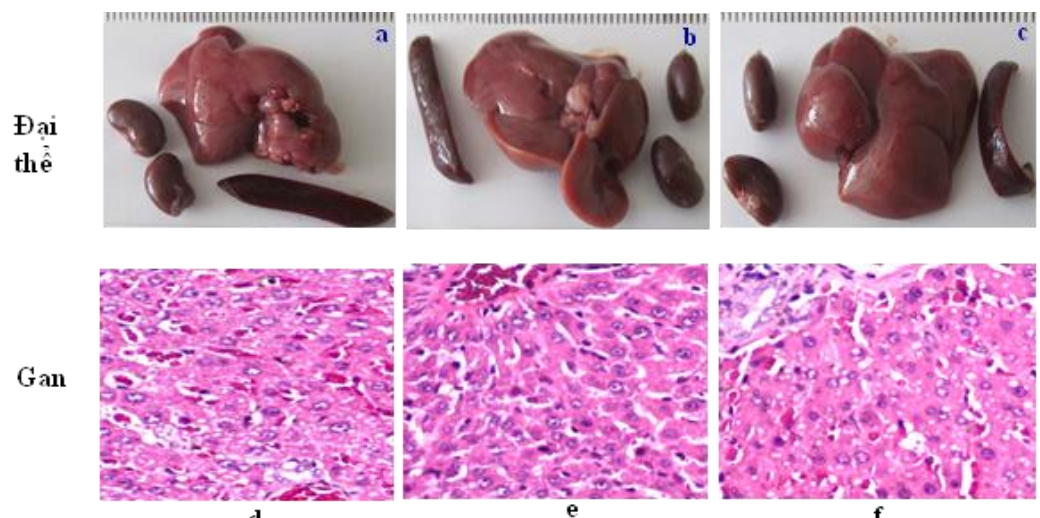

d
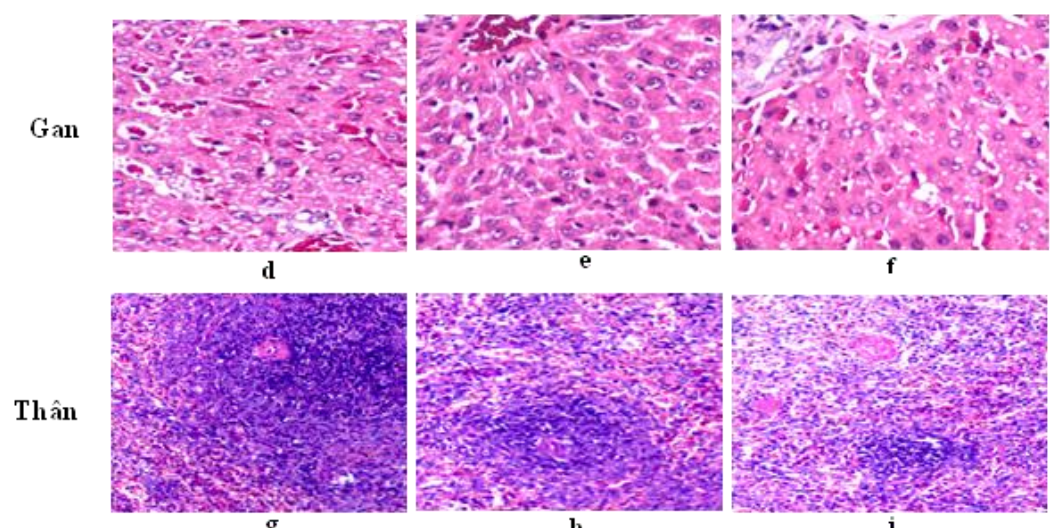

Lách
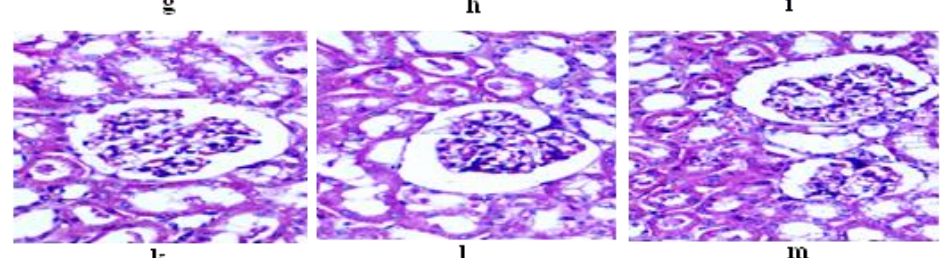

Hình 1. Hình ảnh đại thể và mô bệnh học vi thể của gan, thận, lách chuột sau 60 ngày uống squalene ở lô đối chứng $(\mathrm{a}, \mathrm{d}, \mathrm{g}, \mathrm{k})$, lô trị $1(\mathrm{~b}, \mathrm{e}, \mathrm{h}, \mathrm{l})$ và lô trị $2(\mathrm{c}, \mathrm{f}, \mathrm{i}, \mathrm{m})$, tương ứng $(\mathrm{HE}, \mathrm{x} 400)$ Ghi chú: Lô chứng: uống dầu oliver liều $1,00 \mathrm{~mL} / \mathrm{kg} / \mathrm{ngày}$; Lô trị 1: uống squalene (pha trong dầu oliver), liều $400 \mathrm{mg} / \mathrm{kg} / \mathrm{ngày}$; Lô trị 2: uống squalene (pha trong dầu oliver)

liều $1.200 \mathrm{mg} / \mathrm{kg} /$ ngày

Kết quả thu được trên hình 1 cho thấy, sau 30 ngày và 60 ngày, chuột được uống squalene từ $S$. mangrovei $\mathrm{PQ6}$ với liều 400 và $1.200 \mathrm{mg} / \mathrm{kg} / \mathrm{ngày}$ đã không gây bất cứ một tổn thương nào ở mô bệnh học gan, thận, lách so với chuột ở lô đối chứng. Kết quả thu được của chúng tôi cũng phù hợp với công bố về tính an toàn của squalene trong các thử 
nghiệm như nghiên cứu độc học khi tiêm dưới $\mathrm{da}$, tiêm bắp và đường hô hấp, kích ứng da và mắt (Sage et al., 1982).

\section{Tác dụng làm tăng HDL-C của squalene trên chuột nhắt trắng thí nghiệm}

HDL-C, lipoprotein - cholesterol tỷ trọng cao, được biết như là cholesterol tốt trong máu vì nó có nhiệm vụ thu dọn, chuyên chở cholesterol dư thừa không cần thiết ở các mô ngoại vi trở về gan và ở gan, phần lớn chúng được biến đổi thành axit mật và bài tiết theo mật ra khỏi cơ thể. Bên cạnh đó, HDL cũng loại bỏ cholesterol lắng đọng trong thành mạch máu, dẫn đến giảm nguy cơ xơ vữa động mạch. Nhiều nghiên cứu đã chỉ ra rằng, những người có nồng độ HDL-C cao trong máu thường ít có nguy cơ mắc bệnh động mạch vành (Silbernagel et al., 2017).

Trong nghiên cứu độc tính bán trình diễn trên chuột cống, chúng tôi đã nhận thấy squalene không những an toàn khi sử dụng mà còn có tác dụng làm tăng nồng độ HDL-C trong máu. Do đó, để làm rõ hơn tác dụng làm tăng chỉ số HDL-C trong máu chuột, chúng tôi đã tiến hành nghiên cứu tác dụng của việc uống squalene lên cơ thể, cân nặng gan, và các chỉ số lipit máu chuột nhắt trắng (bảng 4-5).

Bảng 4. Ảnh hưởng của squalene lên cân nặng cơ thể và gan chuột nghiên cứu ( $\mathrm{n}=8, \bar{X} \pm \mathrm{SD})$

\begin{tabular}{|c|c|c|c|c|}
\hline Thời điểm xét nghiệm & Lô chứng (1) & Lô trị 1 (2) & Lô trị 2 (3) & $p$ \\
\hline \multicolumn{5}{|l|}{ Cân nặng cơ thể chuột $(\mathrm{g})$} \\
\hline Trước thí nghiệm (a) & $18,63 \pm 0,92$ & $18,38 \pm 0,74$ & $18,88 \pm 0,83$ & \multirow{3}{*}{$\begin{array}{l}p_{2-1}>0,05 \\
p_{3-2}>0,05 \\
p_{3-1}>0,05\end{array}$} \\
\hline Sau 30 ngày (b) & $23,88 \pm 1,36$ & $23,38 \pm 1,19$ & $23,75 \pm 1,04$ & \\
\hline Sau 60 ngày (c) & $27,13 \pm 1,13$ & $26,88 \pm 1,36$ & $26,63 \pm 1,51$ & \\
\hline$p$ & \multicolumn{3}{|c|}{$p_{b-a}>0,05 ; p_{c-b}>0,05 ; p_{c-a}>0,05$} & \\
\hline \multicolumn{5}{|l|}{ Cân nặng gan chuột (g) } \\
\hline Sau 60 ngày & $1,48 \pm 0,13$ & $1,45 \pm 0,15$ & $1,44 \pm 0,17$ & $\begin{array}{l}p_{2-1}>0,05 \\
p_{3-2}>0,05 \\
p_{3-1}>0,05\end{array}$ \\
\hline
\end{tabular}

Ghi chú: Lô 1 (chứng): uống dầu oliver; Lô trị 1: uống squalence (pha trong dầu oliver) liều $600 \mathrm{mg} / \mathrm{kg} / \mathrm{ngày}$; Lô trị 2: uống squalene (pha trong dầu oliver) liều $1.200 \mathrm{mg} / \mathrm{kg} / \mathrm{ngày}$.

Kết quả trên bảng 4 cho thấy, không có sự khác biệt có ý nghĩa thống kê về trọng lượng cơ thể và gan của chuột giữa lô chứng và 2 lô trị ở các thời điểm thí nghiệm khác nhau $(p>0,05)$.

Chỉ số HDL-C và tỷ lệ HDL-C/cholesterol toàn phần trong máu chuột ở lô trị 1 và lô trị 2 tăng cao hơn có ý nghĩa thống kê so với lô chứng ( $p<0,05$ và $p<0,01$, tương ứng) (bảng 5). Chỉ số LDL-C và VLDL-C trong máu chuột ở lô trị 1 và lô trị 2 thấp hơn có ý nghĩa thống kê so với lô chứng $(p<0,05)$. Không có sự sai khác có ý nghĩa thống kê về nồng độ cholesterol toàn phần và $\mathrm{TG}$ trong máu chuột khi so sánh giữa các lô với nhau (bảng 5). Kết quả nghiên cứu của chúng tôi cũng hoàn toàn phù hợp với các nghiên cứu của các tác giả khác trên thế giới (Pallavi et al., 2013; Gabás-Rivera et al., 2014).

Như vậy, với liều $600 \mathrm{mg} / \mathrm{kg} / \mathrm{ngày} \mathrm{và} \mathrm{liều}$ $1.200 \mathrm{mg} / \mathrm{kg} /$ ngày cho chuột nhắt trắng uống liên tục trong 60 ngày, squalene có tác dụng làm tăng hàm HDL-C và tỷ lệ HDL$\mathrm{C} /$ cholesterol toàn phần trong máu, làm giảm hàm lượng $L D L-C$ và VLDL-C trong máu và không ảnh hưởng đến các chỉ số cholesterol toàn phần và $\mathrm{TG}$ máu, cân nặng gan và sự phát triển cân nặng cơ thể. 
Bảng 5. Ảnh hưởng của squalene lên các chỉ số lipit máu chuột $(\mathrm{n}=8, \bar{X} \pm \mathrm{SD})$

\begin{tabular}{|l|c|c|c|}
\hline \multicolumn{1}{|c|}{ Chỉ số lipit máu } & Lô chứng & Lô trị 1 & Lô trị 2 \\
\hline Cholesterol TP $(\mathrm{mmol} / \mathrm{L})$ & $3,10 \pm 0,43$ & $2,84 \pm 0,32$ & $2,80 \pm 0,45$ \\
\hline HDL-C (mmol/L) & $0,45 \pm 0,16$ & $0,62^{*} \pm 0,08$ & $0,64^{*} \pm 0,12$ \\
\hline Tỷ lệ HDL-C/ Cholesterol TP & $0,15 \pm 0,06$ & $0,22^{* *} \pm 0,03$ & $0,23^{* *} \pm 0,04$ \\
\hline VLDL + LDL-C & $2,65 \pm 0,46$ & $2,22^{*} \pm 0,28$ & $2,16^{*} \pm 0,39$ \\
\hline Triglycerit (mmol/L) & $0,99 \pm 0,15$ & $0,98 \pm 0.17$ & $0,92 \pm 0,21$ \\
\hline
\end{tabular}

Ghi chú: Lô 1 (chứng): uống dầu oliver; Lô trị 1: uống squalene (pha trong dầu oliver) liều $600 \mathrm{mg} / \mathrm{kg} / 24$ giờ; Lô trị 2: uống squalene (pha trong dầu oliver) liều $1.200 \mathrm{mg} / \mathrm{kg} / 24$ giờ; *: Khác biệt so với lô chứng với $p<0,05 ; * *$ : Khác biệt so với lô chứng với $p<0,01$.

\section{KẾT LUẬN}

Sử dụng squalene liên tục là an toàn và có tác dụng tốt cho trao đổi lipid. Các kết quả nghiên cứu thu được đã cho phép khẳng định có thể sử dụng tốt squalene để làm thực phẩm chức năng cho người trong thời gian tới ở Việt Nam.

\section{TÀI LIỆU THAM KHẢO}

Bộ Y tế, 2018. "Quy định về thử thuốc trên lâm sàng”, Thông tư số 29/2018/TT-BYT ngày 29 tháng 10 năm 2018.

Chan P., Tomlinson B., Lee C. B., Lee Y. S., 1996. Effectiveness and safety of lowdose pravastatin and squalene, alone and in combination, in elderly patients with hypercholesterolemia. J. Clin. Pharmacol., 36: 422-427.

CTFA, (June 11, 1971). Submission of data by CTFA, Leberco Labs. Acute oral LD50*.

Đỗ Trung Đàm, 2014. Phương pháp Litchfield Wilcoxon. Phương pháp xác định độc tính của thuốc. Nxb Y học, 101-112.

Đỗ Trung Đàm, 2006. Phương pháp ngoại suy liều có hiệu quả tương đương giữa người và động vật thí nghiệm. Phương pháp nghiên cứu tác dụng dược lý của thuốc từ dược thảo. $\mathrm{Nxb}$ Khoa học và Kỹ thuật, 377-392.

Gabás-Rivera C., Barranquero C., MartínezBeamonte R., Navarro M. A., Surra J. C., Osada J., 2014. Dietary squalene increases high density lipoprotein-cholesterol and paraoxonase 1 and decreases oxidative stress in mice. PLoS One, 9(8): 9 pp.
Hien H. T. M., Ha N. C., Thom L. T. T., Hong D. D., 2017. Squalene promotes cholesterol homeostasis in macrophage and hepatocyte cells via activation of liver $\mathrm{X}$ receptor (LXR) $\alpha$ and $\beta$. Biotechnol. Lett., 39(8): 1101-1107.

Hoang T. M. H., Nguyen C. H., Le T. T., Hoang T. H. Q., Ngo T. H. T., Hoang T. L. A., Hong D. D., 2016. Squalene isolated from Schizochytrium mangrovei is a peroxisome proliferator-activated receptor-a agonist that regulates lipid metabolism in HepG2 cells. Biotechnol. Lett., 38: 1065-1071.

Kohno Y., Rgawa Y., Itoh S., Nagaoka S., Takahashi M., Makai K., 1995. Kinetic study of quenchinh reaction of singlet oxygen and scavenging reaction of free radical by squalene in n-butanol. Biochim. Biophys. Acta, 1256: 52-56.

Nguyen H. C., Le T. T., Hoang T. H. Q., Pham V. N., Hoang T. L. A, Hong D. D., 2016. Extraction of squalene from Vietnam heterotrophic marine microalga. The 4 the Academic conference on natural Science for Yong Scientists, Master \& $\mathrm{PhD}$ Student from Asean Countries. 1518 December, 2015 - Bangkok, Thailand. Proceeding, p. 46-56.

Pallavi S., Ganesan B., Anandan R., 2013. Beneficial Effect of Dietary Squalene supplementation on Experimentally Induced Cardiomyopathy in Rats. International Journal of Research in Pharmaceutical and Biomedical Sciences, 3: 525-533. 
Pouchert C. J., Behnke J., 1993. The Aldrich Library of $13 \mathrm{C}$ and 1H FTNMR Spectra. Aldrich Chemical Co., Milwaukee, p. 46.

Sage, 1982. Final report on the safety assessment of squalane and squalene. Int. J. Toxicol., 1: 37-56.

Smith T. J., 2000. Squalene: potential chemopreventive agent. Expert Opin. Investig. Drug, 9: 1841-1848.
Silbernagel G., Pagel P., Pfahlert V., Genser B., Scharnagl H., Kleber M. E., Delgado G., Ohrui H., Ritsch A., Grammer T. B., Koenig W., März W., 2017. HighDensity Lipoprotein Subclasses, Coronary Artery Disease, and Cardiovascular Mortality. Clin. Chem., 63(12):1886-1896. 